\title{
植物ウイルス抵抗性の打破：ウイルス抵抗性の永続性を予測したり 延長させたりできるだろらか？
}

\author{
小林 括平 ${ }^{1 *}$ ・関根健太郎 ${ }^{2} \cdot$ 西口 正通 $^{1}$
}

KOBAYASHI, K. ${ }^{1 *}$, SEKINE, K.-T. ${ }^{2}$ and NISHIGUCHI, M. ${ }^{1}$ (2014). Breakdown of plant virus resistance: can we predict and extend the durability of virus resistance?

Key words: plant virus, resistance gene, breakdown, durability, prediction, genetic background

植物ウイルス病害の防除には，既存の抵抗性遺伝子を交 配育種によって導入した品種あるいは遺伝子組換えによって 抵抗性を付与した品種の利用や, 弱毒ウイルスを用いた交 叉防御, あるいは媒介生物の化学的防除などさまざまな方 法が用いられている. そのらち, 天然の抵抗性遺伝子を持 つ品種の利用は経済性, 省力性拉よび長年の利用経験から くる消費者の安心感などの点で最も有用な防除手段である. しかし, 新しいウイルス系統の出現によって抵抗性が打破 され，大きな被害が出る事例が数多く経験されている。 ウ イルス抵抗性が打破されず, 持続的に有効な防除手段であ り続ける性質を「durability（永続性）」と呼び, 多くの植物 病理学括よび育種学分野の研究者の関心を集めている. 本 総説では抵抗性打破の事例をいくつか示すとともに, 抵抗 性打破に関するリスク評価や永続性の延長を目指した最近 の研究を紹介する.

\section{1. 植物のウイルス抵抗性}

ウイルスが植物細胞に感染すると，まず遺伝子を発現し， 合成されたタンパク質を用いて複製し,ささら細胞間移行, 植物体内での長距離移行扔よび植物体間の移行によって感 染を拡大させていく. それに対して植物は, それらの各ス テップを抑制するさまざまなメカニズムの抵抗性を進化さ せてきた（高橋, 2004). Table 1 飞代表的な抵抗性遺伝子 を示す. クラス 1 抵抗性遺伝子は, 最も広範な植物で認め
られる、いわゆる免疫レセプターをコードする遺伝子であ り, 多くは過敏感反応 (HR) を伴う抵抗性を支配する (Moffett, 2009)。このクラスの抵抗性遺伝子にコードされるタンパク 質は, NB-ARC (nucleotide-binding adaptor shared by APAF$1, \underline{R}$ proteins, and $\underline{C E D}-4)$ ドメインおよび LRR (leucine-rich repeat）ドメインを持つことから NB-LRR タンパク質と呼 ばれ，ウイルス以外の病原体に対する抵抗性タンパク質と も共通した構造を持つ（Dangl and Jones, 2001).

クラス 2 抵抗性遺伝子はウイルスの感染サイクルに必要 な宿主因子の劣性アレルであり, 翻訳開始因子 $\mathrm{eIF} 4 \mathrm{E}$ 拉よ び eIF(iso)4E の遺伝子がその代表例である。これらの翻訳 開始因子はポティウイルスの VPg と相互作用寸ることが知 られている (Robaglia and Caranta, 2006)。また, 翻訳開始 因子はキャップ構造を持つ RNA ウイルス (Yoshii et al., 2004）およびこれを持たないRNA ウイルスとの相互作用に も関与する (Truniger et al., 2008). ウイルス複製に必須の

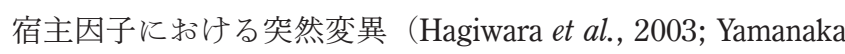
et al., 2002）も劣性のウイルス抵抗性遺伝子として有用と考 えられるが，これまで翻訳開始因子のアレル以外に作物に 導入されて利用されているものはない，ウイルスの宿主範 囲を決定する要因として細胞間移行の成否がある (Furusawa and Okuno, 1978; Meshi et al., 1987; Nishiguchi et al., 1980). その特異性を決定する宿主遺伝子もクラス 2 抵抗性遺伝子 と見なせるが，これまで同定されていない。

\footnotetext{
1 愛媛大学農学部（† 790-8566 愛媛県松山市樽味 3-5-7） Faculty of Agriculture, Ehime University, Ehime 790-8566, Japan

2 (公財) 岩手生物工学研究センター（干 024-0003 岩手県北上市成田 22-174-4） Iwate Biotechnology Research Center, Iwate 0240003, Japan

*Corresponding author (E-mail: kappei@ehime-u.ac.jp)

この総説は先に Journal of General Plant Pathology の 80 巻 4 号の pp. $327 \sim 336$ に掲載された総説（http://dx.doi.org/10.1007/s10327014-0527-1）の抄訳です．報文としてのプライオリティーはJGPP 掲載の総説にありますので，引用の際には本総説ではなくJGPP の 総説を用いるようにご注意ください.
} 
Table 1. Classification of natural plant virus resistance genes.

\begin{tabular}{|c|c|c|c|c|}
\hline Class & Gene products ${ }^{\mathrm{a}}$ & Inheritance $\mathrm{e}^{\mathrm{b}}$ & Resistance $^{c}$ & Examples (gene names or protein names) \\
\hline 1 & NB-LRR R-proteins & Dominant & $\mathrm{HR}^{\mathrm{d}}$ and $\mathrm{ER}^{\mathrm{e}}$ & $H R T, L, N, N, R C Y 1, R x, S w-5, T m-2, T m-2^{2}$, etc. \\
\hline 2 & Essential host factors & Recessive & Gene expression & $\begin{array}{l}\text { Pvr } 1, m o 1, s b m 1, l s p-1^{*} \text {, etc. (encoding eIF } 4 \mathrm{E} \text { or } \\
\text { eIF(iso) } 4 \mathrm{E} \text { ) }\end{array}$ \\
\hline \multirow{4}{*}{ others } & & & Replication & tom- $1^{*}$, tom $-2^{*}$, tom- $3^{*}$, etc. \\
\hline & Jacalin-type lectins & Dominant & $\mathrm{LDM}^{\mathrm{f}}$, Replication & RTM1, JAX1 \\
\hline & Small heat shock-like & Dominant & LDM & RTM2 \\
\hline & Inhibitor of replication & Incompletely dominant & Replication & $T m-1$ \\
\hline
\end{tabular}

${ }^{\text {a }}$ Protein products encoded by the natural resistance genes

${ }^{\mathrm{b}}$ The mode of inheritance of the natural resistance genes

${ }^{\mathrm{c}}$ Resistance phenotype or resistance target

${ }^{\mathrm{d}}$ Hypersensitive reaction

e Extreme resistance

${ }^{\mathrm{f}}$ Long-distance movement

* These are mutants of Arabidopsis thaliana genes isolated after artificial mutagenesis and phenotypic screening.

RNA サイレンシングはウイルスに対する基礎的な防御機 構として受け入れられている (Wang et al., 2012). ウイルス はこれに対抗してサイレンシング抑制因子（VSRs）を進化 させたが, VSRs はクラス 1 抵抗性遺伝子の標的とされてい ることが多く, RNA サイレンシングとクラス 1 の抵抗性が 植物とウイルスの進化上の軍拡競争に重要であることが示 唆される (Moffett, 2009).

近年, クラス 1 打よび 2 に属さない抵抗性遺伝子に関す る理解が進んで拈り, シロイヌナズナのポティウイルス抵 抗性を主導する複数の因子（Cosson et al., 2012），ポテック スウイルスに対する抵抗性に関わるレクチン様タンパク質 (Yamaji et al., 2012)，扣よびウイルスの複製酵素と複合体を 形成して複製を阻害する宿主タンパク質 (Ishibashi et al., 2012）などが知られている.

\section{2. クラス 1 ウイルス抵抗性の打破}

クラス 1 抵抗性遺伝子は, 植物とウイルスの間の軍拡競 争によって進化してきたと考えられる植物病害抵抗性遺伝 子ファミリーに属する (Jones and Dangl, 2006). 植物は病原 体感染を受けた際, 病原体関連分子パターン（PAMPs）を パターン認識レセプターで認識し, PAMPs 誘導性免疫 (PTI) を活性化する (Boller and He, 2009). 一方, 病原体はPTI を打ち破るために病原因子として種々のエフェクターを進 化させた（Göhre and Robatzek, 2008). 植物はエフェクター を非病原力 (Avr) 因子として認識する免疫レセプターを進 化させ, エフェクタ一誘導性免疫と呼ばれるより強い抵抗性 機構を持つに至った. RNA サイレンシングはウイルスに対 するPTIに準ずるものと考えられ，その抑制因子である VSRs はウイルスの病原力エフェクターと考觉られる. その
エフェクターを Avr 因子として認識するのがクラス 1 抵抗性 遺伝子がコードする免疫レセプターである (Moffett, 2009).

細菌，拈よび糸状菌などの真核生物である病原体では， エフェクターを失ったり，新たなものを獲得したりすること によって抵抗性を打破することができる.しかし，ウイル スゲノムがコードできるタンパク質には限りがあり，さら に多くの場合，ウイルスタンパク質は多機能性で病原因子 としての機能以外の重要な機能を担っていることが多い. そのため, ウイルス抵抗性の打破は, もっぱらウイルスタ ンパク質の変異によって起こる. たとえば, トマトのトマト モザイクウイルス（ToMV）抵抗性遺伝子 $T m-2$ 打よび $T m-2^{2}$ は ToMVの細胞間移行因子（MP）を認識するが，MP の変異 によって打破されることが分かっている（Meshi et al., 1989）. 興味深いことに，より永続的な，すなわち打破されにく いTm- $2^{2}$ を打破する ToMV 系統は特に低い病原性を示す (Lanfermeijer et al., 2003). 同様に，トウガラシ微斑ウイルス (PMMoV) の $L^{3}$ 抵抗性打破系統は, 非打破系統よりも適応 度が低く（Sakamoto et al., 2008），抵抗性打破には感染能の 低下が伴らと考光られる。しかし，それでも多くの抵抗性 打破の事例が報告されている（García-Arenal and McDonald, 2003).

ジャガイモウイルス X (PVX) に対して抵抗性遺伝子 $R x 1$ およびRx2 は高度抵抗性（ER）を示すが，HRをともなう 抵抗反応を支配する抵抗性遺伝子と同様に NB-LRR 型の免 疫レセプターをコードし，Rxの Avr 因子である PVX の外被 タンパク質 $(\mathrm{CP})$ と一過性発現系で共発現させると HR 様の 細胞死を誘導する（Bendahmane et al., 2000）. このことから $\mathrm{ER}$ も HRをともなら抵抗性と同じシグナル伝達系に依存し ていることが示唆される，事実，HRをともなら抵抗反応を 
支配する抵抗性遺伝子を高発現させると ER を示す（Sekine et al., 2008; Tomita et al., 2011).

クラス 1 抵抗性遺伝子産物は病原体を認識するレセプ ターであり, その打破は認識の回避によって起こる. 完全 に認識を回避して感受性病徵を発現する抵抗性打破変異ウ イルスもある. しかし, 認識の回避が不完全なものでは遅 延型の抵抗反応が起こり, 壊死性の病徵を発現させるため, 被害は感受性品種を利用した場合よりも大きくなることも ある. 近年の研究から全身壊死は, HR 誘導と同じ分子機構 によることが示され（Atsumi et al., 2009; Komatsu et al., 2010), 不完全に打破された抵抗性遺伝子によって起こることが示 唆される (Sekine et al., 2006)。 そ礼ゆ光，クラス 1 抵抗性 の打破に関するリスクについて注意が必要である.

\section{3. クラス 2 ウイルス抵抗性の打破}

クラス 2 抵抗性遺伝子はウイルスの感染サイクルに重要 なプロセスに関与する宿主因子のアレルである。それ和え， このクラスの抵抗性は宿主因子がウイルス側の因子と相互 作用しないことに依存している. たとえば，翻訳開始因子 eIF4E/eIF(iso)4E とポティウイルス VPg との相互作用の重 要性は, そ饥らの物理的相互作用とウイルスの感染性との 関係, 打よびシロイヌナズナの変異体を用いた遺伝学的解 析によって示され, さらには, 劣性のポティウイルス抵抗 性が eIF4E/eIF(iso)4E のアレルであることが示された（Gao et al., 2004; Kang et al., 2005; Léonard et al., 2004; Nicaise et al., 2003; Ruffel et al., 2005). これによって, ウイルスの感染サ イクルに重要なプロセスに関与する宿主因子のアレルが劣 性の抵抗性遺伝子となるといら概念が確立した。これまで に実用作物品種においてょく研究されているのは, クラス 2 では eIF4E/eIF(iso)4E だけであり, 他のクラス 2 抵抗性の 打破については言及しない。

eIF4E/eIF(iso)4E が抵抗性遺伝子として機能するメカニズ ムとして, 単純に翻訳効率がウイルス感染の成否を決めて いることが考兄られる。キャップのある，あるいはキャッ プのないRNAをゲノムとして持つウイルスの場合はこの図 式が成り立つようである（Truniger et al., 2008; Yoshii et al., 2004). しかし，ポティウイルスと eIF4E/eIF(iso)4E の相互 作用はそう単純ではない. 確かに抵抗性のアレルにコード される eIF $4 \mathrm{E} / \mathrm{eIF}$ (iso) $4 \mathrm{E}$ はV V g と相互作用せず，抵抗性 打破株の VPg に認められる変異は相互作用を回復させる (Charron et al., 2008; Roudet-Tavert et al., 2007; Yeam et al., 2007). しかし, 他のポティウイルス遺伝子の変異も劣性の ポティウイルス抵抗性の打破に寄与する (Abdul-Razzak et al., 2009; Nakahara et al., 2010; Tavert-Roudet et al., 2012). ダ
イズの sbm1 遺伝子は $\mathrm{eIF} 4 \mathrm{E}$ をコードて扔り, ウイルス の感染拡大を抑制するが，最初に感染した細胞に打ける ウイルス RNAの翻訳にはあまり影響しない (Ashby et al., 2011)。これらの結果から, eIF4Eを介する抵抗性は単なる 翻訳の低下によるものではなく, ウイルス感染サイクルの いずれかのステップに括衫複雑な分子間相互作用による ものであることが示唆される.

クラス 1 のウイルス抵抗性と異なり, クラス 2 抵抗性遺 伝子はその抵抗性メカニズムに細胞死は関与しないため, 打破された場合にも全身壊死のよらな重篤な症状を示すり スクはない，そのため, クラス 2 抵抗性遺伝子はクラス 1 よりも抵抗性品種の育種に適していると言えるだろう.

\section{4. 抵抗性打破リスクの評価}

\section{（1）インフォマティクスによる抵抗性打破リスクの評価}

抵抗性打破は農業生産に大きな被害を与兄らるため, 抵 抗性打破のリスクを評価しようとする研究が行われた，古典 的な研究（García-Arenal and McDonald, 2003）では，抵抗性 の打破に関する膨大な資料を基に抵抗性打破りスクを評価 する指標として「進化ポテンシャル」を以下の 3 つの基準 で算定している．1）次の宿主に感染しうるウイルスの有効 ポピュレーションサイズ：宿主範囲が広いほど，伝搬効率 が高いほど，また，ウイルスが安定であるほど高リスクで ある. 2) 遺伝子流動性あるいはウイルスの伝搬能:ベクター や人間の活動の関与を問わず, ウイルスがどれだけの距離 を移動しらるかによって評価され，大きいほど高リスクで ある. 3）複製機構：ウイルス系統間での遺伝情報を交換し らるかどらかによって評価され，高頻度であるほど高りス クである. この研究は抵抗性打破汇関わる遺伝子変異つい て考慮して拈らず， $T m-1$ 打よび $T m-2^{2}$ で見られるよらな同 じ植物とウイルスの組合せに打壮る異なる抵抗性遺伝子の 打破リスクの違いを説明できない，最近の研究では，抵抗 性打破変異ウイルスのAvr 因子の变異による適応度の低下 に注目したものがある（Janzac et al., 2009）。彼らは，抵抗 性打破变異株の適応度を評価するために抵抗性打破リスク とAvr 因子の多様性の関係を解析し, 同義置換と非同義置 換の比が抵抗性打破のリスクと相関することを見出し， ウ イルスのAvr 因子の進化に対する制約によって抵抗性打破 リスクを評価できると結論した。 しかし，このアプローチ も $T m-1$ 特よび $T m-2^{2}$ のよらに共通するウイルス Avr 因子 を認識する抵抗性遺伝子の永続性の違いを説明できない.

別の研究では, 感染過程の詳細な数学モデルを利用して いる (Fabre et al., 2009). この研究は, 具体的なウイルス抵 抗性の打破については何ら言及していないが，抵抗性打破 
リスクと相関するいくつかのパラメーターを明確に示した. すなわち，抵抗性打破に必要な変異の数，それらの变異が トランジションかトランスバージョンかといら特性, ウイ ルスの変異率，㧊よび変異ウイルスの適応度がどれほど低 下したかの 4 点である. 上述のように理論的な抵抗性打破 リスクの予測は，すべての抵抗性遺伝子に適用できるわけ ではなかった。それに対し，この数学モデルから導き出さ れた重要なパラメーターは, 疫学調査あるいは実験による 研究の結果から抵抗性打破のリスクを予測するのに役立つ だろら。化学変異原処理やエラープローン PCR よ゙で変異 を導入したウイルス集団を用いることで各パラメーターを 実験的に決定し，ょり信頼性の高い抵抗性打破リスクの評 価が可能になるだろう.

（2）構造生物学的手法による抵抗性打破リスクの評価

クラス 1 扎よび 2 , いずれのウイルス抵抗性に打いても, その分子レベルの基盤となるのはタンパク質間相互作用で あり，それゆ分子間相互作用の研究を進めることによっ て抵抗性打破に結びつくウイルスタンパク質の構造変化を 予測できるかもしれない. クラス 2 の抵抗性に関しては, eIF4E の立体構造はすでに決定され (Marcotrigiano et al., 1997)，抵抗性に関与するアミノ酸残基の位置は三次構造中 で決定されている (Ashby et al., 2011; Yeam et al., 2007). し かし，ポティウイルスの VPgに関しては相同性に基づく分 子モデリングの報告があるだけで，実際の構造は決定され ていない (Jebasingh et al., 2011; Plochocka et al., 1996). VPg は不定形タンパク質であるとする報告もある（Grzela et al., 2008; Rantalainen et al., 2011). それゆ変異 VPg がウイルス 感染サイクルにおいて機能し得るかどらかをアミノ酸配列 から予測することは困難であろら。

クラス 1 抵抗性遺伝子産物によるウイルス認識機構の研 究に基づく抵抗性打破リスクの評価も困難だが，魅力的な 研究分野である。これまでに多くの NB-LRR 型の抵抗性タン パク質が遺伝子クローニングされた（Moffett, 2009). 抵抗 性タンパク質による病原体認識機構は多様なものと考光ら れるが，ベイト・アンド・スイッチモデルと名付けられた 包括的なモデルが提唱された（Collier and Moffett, 2009). このモデルでは，NBの $\mathrm{N}$ 末端側のドメインと相互作用する 第三のタンパク質（ベイト＝罠に仕掛けるエサ）を想定す るが，これが病原性因子としてのエフェクタ一の標的また はそのデュイ（括とり）であり，これにおびき寄せられた エフェクターを抵抗性タンパク質が認識するといらモデル である。これまでにいくつかのベイトとして働くたんぱく 質が同定されているが, ウイルス抵抗性タンパク質に関し ては，NRIP1 と RanGAP2 の二種類が知られているに過ぎな
い（Caplan et al., 2008; Sacco et al., 2007). ベイトタンパク質 の病原体認識に打ける重要性は明らかであるが，しかし，病 原体認識の特異性を決定しているのはLRRドメインである.

LRR ドメインが抵抗性タンパク質の特異性決定に重要であ ることはこれまでにたびたび示されている（Moffett, 2009). PVX 抵抗性遺伝子である $R x$ では，ランダムな変異導入に よって，認識できるウイルス系統およびウイルス種の範囲 が広くなったことが報告されている（Farnham and Baulcombe, 2006). 同様な認識範囲の拡大は進化の過程でも起こったと 考学られる。トウガラシ属植物のトバモウイルス抵抗性 $L$ 遺伝子には 4 種類のアレル, $L^{1}, L^{2}, L^{3}$ および $L^{4}$ があり， これらはトバモウイルスの CPをAvr として認識するが，そ の認識範囲は階層的に異なる (Tomita et al., 2011). $L^{1}$ アレ ルよりも $L^{2}$ は多くのトバモウイルスを認識でき，さらに $L^{3}$ アレルおよび $L^{4}$ はより広範なトバモウイルスを認識できる が， $L^{4}$ を打破する $\mathrm{P}_{1,2,3,4}$ 病原型の $\mathrm{PMMoV}$ もすでに出現し ている（Genda et al., 2007)．遺伝子クローニング，キメラ 解析抏よび変異解析によって $L$ 遺伝子の各アレルとトバモ ウイルス $\mathrm{CP}$ の階層的な相互作用が $\mathrm{L}$ 抵抗性タンパク質の LRR ドメインの複数の反復単位と CP との相互作用によっ て成り立つことが示された（Tomita et al., 2011）.Nicotiana sylvestris の $N^{\prime}$ 遺伝子はタバコモザイクウイルス（TMV）以 外の広範なトバモウイルスに対する抵抗性を支配し，CPを Avr として認識することからトウガラシ属の $L$ 遺伝子のパ ラログと考光られてきた (Culver, 2002). キメラ解析によっ て $\mathrm{N}^{\prime}$ および L 抵抗性タンパク質の認識特性はやはり LRR ド メインが担って扣り，それらのアミノ酸配列は $89.2 \%$ と高い 類似性を示すが CP の認識様式は異なっていることが示さ れた（Sekine et al., 2012）。

NB-LRR 型の抵抗性タンパク質による病原体認識に打け る LRR ドメインの重要性にもかかわらず，LRR と Avr 因 子の分子間相互作用についてはほとんぞ分かっていない. Nicotiana glutinosa 由来のトバモウイルス抵抗性 $N$ 遺伝子は, Avr 因子である p50 と直接相互作用することが報告されてい るが，LRRだけでは相互作用することはできず，NB-LRRの 形でのみ p50 と相互作用する (Ueda et al., 2006). 以上のこ とを総合すると，現時点では抵抗性タンパク質と Avr 因子 の構造から抵抗性打破のリスクを評価するのは技術的に困 難と考兄られる. 分子構造に基づく論理的な抵抗性打破り スク評価と永続的な抵抗性を合理的に設計するためには, 抵抗性タンパク質の高次構造や分子間相互作用についてさ らに研究を進める必要がある。

クラス 1 抵抗性遺伝子に共通した特徵に温度感受性があ る (Richael and Gilchrist, 1999; Wang et al., 2009; Whitham et 
al., 1996). 抵抗性品種が高温にさらされると抵抗性遺伝子 が機能しなくなり病原体が増殖するが, 温度が下がると増 殖した病原体は抵抗性遺伝子による選択圧を受ける。この ような増殖と選択の繰り返しは, 抵抗性打破のリスクを増 大寸るであろら。トウガラシ属のトバモウイルス抵抗性遺 伝子, $L$ 遺伝子には高温機能性のアレル， $L^{1 a}$ が知られている (Sawada et al., 2004)．この高温機能性のメカニズムを明ら かにすれば，永続的な抵抗性を開発する一助となるだろう。

\section{5. 抵抗性遺伝子の永続性を高める方法}

クラスに関わらず，それぞれの抵抗性遺伝子はその永続 性に扣いて千差万別である. 新規の抵抗性遺伝子を発見す ることや既知の抵抗性遺伝子の永続性を高めることは容易 ではないので，抵抗性遺伝子の永続性を高めるには別の方 法を考兄なければならない。抵抗性遺伝子の永続性に対す る遺伝的背景の効果に関する最近の研究は非常に示唆に富む. 遺伝的背景とは病害抵抗性に関与寸る量的遺伝子座 (QTLs) の有無を指す。病害抵抗性に関与する QTLsは，いわゆる 抵抗性遺伝子のように病原体を完全に抑制することはでき ないが，病害の程度を抑制することができるもので，QRLs (quantitative resistance loci; Poland et al., 2009) とも呼ばれる. QRLs があると, ウイルス, 系状菌打よび線虫に対する抵抗 性遺伝子が打破を免れることが示された（Brun et al., 2010; Fournet et al., 2013; Palloix et al., 2009). QRLs による永続性 の向上のメカニズムに関する研究では, QRLsの存在によっ て打破に必要な病原体の変異数が多くなることが示された (Quenouille, et al., 2013).これらの研究は, たと兄個々の遺伝 子の効果は小さくとも，それらを組久合わせて使用するこ とは，持続的な病害防除に有用であることを強く示唆する.

\section{おわりに}

ウイルス抵抗性遺伝子の打破は不可避であり, 世界中で 農業生産の脅威であり続ける。 それゆ无我々は植物病理学 100 年の歴史からより多くを学び, 永続的な病害防除のための 基礎抢よび応用研究を推進しなければならない，抵抗性主働 遺伝子の永続性に対する遺伝的背景の効果に関する洞察に 富む研究を紹介したが (Palloix et al., 2009; Quenouille et al., 2013)，これらの研究は抵抗性遺伝子を組及合わせて使用す ることの有用性に加光，さまざまな防除戦略を組久合わせて 用いることの重要性を想起させる．既知の病害に対しても 有用な新規抵抗性遺伝子を発見するのは容易ではないため, 抵抗性が打破された場合には，遺伝子組換えによる抵抗性 を利用する可能性も排除すべきではない，一方，新興病害 に対しては, 抵抗性主働遺伝子と並行してQRLs の探索に
も取り組むべきであろら。ゲノム科学の発展によって, QTLs の同定や育種系統にそ机らを導入するピラミッディン グも困難ではなくなっているが，それでも新規抵抗性品種 の開発には時間がかかる。これらの新しい技術と従来からあ る耕種的防除技術を組久合わせて使用することで，持続的 な病害防除への道が開かれるだらう。

\section{引用文献}

Abdul-Razzak, A., Guiraud, T., Peypelut, M., Walter, J., Houvenaghel, M.C., Candresse, T., Le Gall, O. and German-Retana, S. (2009). Involvement of the cylindrical inclusion (CI) protein in the overcoming of an eIF4E-mediated resistance against Lettuce mosaic potyvirus. Mol. Plant Pathol. 10: 109-113.

Ashby, J.A., Stevenson, C.E.M., Jarvis, G.E., Lawson, D.M. and Maule, A.J. (2011). Structure-based mutational analysis of eIF $4 \mathrm{E}$ in relation to $\operatorname{sbm} 1$ resistance to pea seed-borne mosaic virus in pea. PLoS One 6: e15873.

Atsumi, G., Kagaya, U., Kitazawa, H., Nakahara, K.S. and Uyeda, I. (2009). Activation of the salicylic acid signaling pathway enhances Clover yellow vein virus virulence in susceptible pea cultivars. Mol. Plant-Microbe Interact. 22: 166-175.

Bendahmane, A., Querci, M., Kanyuka, K. and Baulcombe, D.C. (2000). Agrobacterium transient expression system as a tool for the isolation of disease resistance genes: application to the $R \times 2$ locus in potato. Plant J. 21: 73-81.

Boller, T. and He, S.Y. (2009). Innate immunity in plants: an arms race between pattern recognition receptors in plants and effectors in microbial pathogens. Science 324: 742-744.

Brun, H., Chévre, A.M., Fitt, B.D.L., Powers, S., Besnard, A.L., Ermel, M., Huteau, V., Marquer, B., Eber, F., Renard, M. and Andrivon, D. (2010). Quantitative resistance increases the durability of qualitative resistance to Leptosphaeria maculans in Brassica napus. New Phytol. 185: 285-299.

Caplan, J.L., Mamillapalli, P., Burch-Smith, T.M., Czymmek, K. and Dinesh-Kumar, S.P. (2008). Chloroplastic protein NRIP1 mediates innate immune receptor recognition of a viral effector. Cell 132: 449-462.

Charron, C., Nicolai, M., Gallois, J.L., Robaglia, C., Moury, B., Palloix, A. and Caranta, C. (2008). Natural variation and functional analyses provide evidence for co-evolution between plant eIF4E and potyviral VPg. Plant J. 54: 56-68.

Collier, S.M. and Moffett, P. (2009). NB-LRRs work a "bait and switch" on pathogens. Trends Plant Sci. 14: 521-529.

Cosson, P., Schurdi-Levraud, V., Le, Q.H., Sicard, O., Caballero, M., Roux, F., Le Gall, O., Candresse, T. and Revers, F. (2012). The RTM resistance to potyviruses in Arabidopsis thaliana: natural variation of the RTM genes and evidence for the implication of additional genes. PLoS One 7: e39169.

Culver, J.N. (2002). Tobacco mosaic virus assembly and disassembly: determinants in pathogenicity and resistance. Annu. Rev. Phytopathol. 40: 287-308.

Dangl, J.L. and Jones, J.D.G. (2001). Plant pathogens and integrated defence responses to infection. Nature 411: 826-833.

Fabre, F., Bruchou, C., Palloix, A. and Moury, B. (2009). Key determinants of resistance durability to plant viruses: insights from 
a model linking within- and between-host dynamics. Virus Res. 141: 140-149.

Farnham, G. and Baulcombe, D.C. (2006). Artificial evolution extends the spectrum of viruses that are targeted by a diseaseresistance gene from potato. Proc. Natl. Acad. Sci. U S A 103: 18828-18833.

Fournet, S., Kerlan, M.C., Renault, L., Dantec, J.P., Rouaux, C. and Montarry, J. (2013). Selection of nematodes by resistant plants has implications for local adaptation and cross-virulence. Plant Pathol. 62: 184-193.

Furusawa, I. and Okuno, T. (1978). Infection with BMV of mesophyll protoplasts isolated from five plant species. J. Gen. Virol. 40: 489-491.

Gao, Z., Johansen, E., Eyers, S., Thomas, C.L., Noel Ellis, T.H. and Maule, A.J. (2004). The potyvirus recessive resistance gene, $s b m 1$, identifies a novel role for translation initiation factor eIF4E in cell-to-cell trafficking. Plant J. 40: 376-385.

García-Arenal, F. and McDonald, B.A. (2003). An analysis of the durability of resistance to plant viruses. Phytopathology 93: 941-952.

Genda, Y., Kanda, A., Hamada, H., Sato, K., Ohnishi, J. and Tsuda, S. (2007). Two amino acid substitutions in the coat protein of Pepper mild mottle virus are responsible for overcoming the $L^{4}$ gene-mediated resistance in Capsicum spp. Phytopathology 97: 787-793.

Göhre, V. and Robatzek, S. (2008). Breaking the barriers: microbial effector molecules subvert plant immunity. Annu. Rev. Phytopathol. 46: 189-215.

Grzela, R., Szolajska, E., Ebel, C., Madern, D., Favier, A., Wojtal, I., Zagorski, W. and Chroboczek, J. (2008). Virulence factor of potato virus $\mathrm{Y}$, genome-attached terminal protein $\mathrm{VPg}$, is a highly disordered protein. J. Biol. Chem. 283: 213-221.

Hagiwara, Y., Komoda, K., Yamanaka, T., Tamai, A., Meshi, T., Funada, R., Tsuchiya, T., Naito, S. and Ishikawa, M. (2003). Subcellular localization of host and viral proteins associated with tobamovirus RNA replication. EMBO J. 22: 344-353.

Ishibashi, K., Mawatari, N., Miyashita, S., Kishino, H., Meshi, T. and Ishikawa, M. (2012). Coevolution and hierarchical interactions of Tomato mosaic virus and the resistance gene Tm-1. PLoS Pathog. 8: e1002975.

Janzac, B., Fabre, F., Palloix, A. and Moury, B. (2009). Constraints on evolution of virus avirulence factors predict the durability of corresponding plant resistances. Mol. Plant Pathol. 10: 599_ 610 .

Jebasingh, T., Jose, M., Kasin Yadunandam, A., Bachiyarani, S., Srividhya, K.V., Krishnaswamy, S. and Usha, R. (2011). Molecular modeling and conformational analysis of native and refolded genome-linked protein of Cardamon mosaic virus. Indian J. Biochem. Biophys. 48: 336-340.

Jones, J.D.G. and Dangl, J.L. (2006). The plant immune system. Nature 444: 323-329.

Kang, B.C., Yeam, I., Frantz, J.D., Murphy, J.F. and Jahn, M.M. (2005). The pvr1 locus in Capsicum encodes a translation initiation factor eIF4E that interacts with Tobacco etch virus VPg. Plant. J. 42: 392-405.

Komatsu, K., Hashimoto, M., Ozeki, J., Yamaji, Y., Maejima, K., Senshu, H., Himeno, M., Okano, Y., Kagiwada, S. and Namba,
S. (2010). Viral-induced systemic necrosis in plants involves both programmed cell death and the inhibition of viral multiplication, which are regulated by independent pathways. Mol. Plant-Microbe Interact. 23: 283-293.

Lanfermeijer, F.C., Dijkhuis, J., Sturre, M.J.G., de Haan, P. and Hille, J. (2003). Cloning and characterization of the durable tomato mosaic virus resistance gene $T m-2^{2}$ from Lycopersicon esculentum. Plant. Mol. Biol. 52: 1037-1049.

Léonard, S., Viel, C., Beauchemin, C., Daigneault, N., Fortin, M.G. and Laliberté, J.F. (2004). Interaction of VPg-Pro of Turnip mosaic virus with the translation initiation factor $4 \mathrm{E}$ and the poly(A)-binding protein in planta. J. Gen. Virol. 85: 1055-1063.

Marcotrigiano, J., Gingras, A.C., Sonenberg, N. and Burley, S.K. (1997). Cocrystal structure of the messenger RNA 5'capbinding protein (eIF4E) bound to 7-methyl-GDP. Cell 89: 951961.

Meshi, T., Watanabe, Y., Saito, T., Sugimoto, A., Maeda, T. and Okada, Y. (1987). Function of the $30 \mathrm{kd}$ protein of tobacco mosaic virus: involvement in cell-to-cell movement and dispensability for replication. EMBO J. 6: 2557-2563.

Meshi, T., Motoyoshi, F., Maeda, T., Yoshiwoka, S., Watanabe, H. and Okada, Y. (1989). Mutations in the tobacco mosaic virus $30-\mathrm{kD}$ protein gene overcome $\mathrm{Tm}-2$ resistance in tomato. Plant Cell 1: 515-522.

Moffett, P. (2009). Mechanisms of recognition in dominant $R$ gene mediated resistance. Adv. Virus Res. 75: 1-33.

Nakahara, K.S., Shimada, R., Choi, S.H., Yamamoto, H., Shao, J. and Uyeda, I. (2010). Involvement of the P1 cistron in overcoming eIF4E-mediated recessive resistance against Clover yellow vein virus in pea. Mol. Plant-Microbe Interact. 23: 1460-1469.

Nicaise, V., German-Retana, S., Sanjuán, R., Dubrana, M.P., Mazier, M., Maisonneuve, B., Candresse, T., Caranta, C. and LeGall, O. (2003). The eukaryotic translation initiation factor $4 \mathrm{E}$ controls lettuce susceptibility to the Potyvirus Lettuce mosaic virus. Plant Physiol. 132: 1272-1282.

Nishiguchi, M., Motoyoshi, F. and Oshima, N. (1980). Further investigation of a temperature-sensitive strain of Tobacco mosaic virus: Its behaviour in tomato leaf epidermis. J. Gen. Virol. 46: 497-500.

Palloix, A., Ayme, V. and Moury, B. (2009). Durability of plant major resistance genes to pathogens depends on the genetic background, experimental evidence and consequences for breeding strategies. New Phytol. 183: 190-199.

Plochocka, D., Welnicki, M., Zielenkiewicz, P. and Ostoja-Zagórski, W. (1996). Three-dimensional model of the potyviral genomelinked protein. Proc. Natl. Acad. Sci. U S A 93: 12150-12154.

Poland, J.A., Balint-Kurti, P.J., Wisser, R.J., Pratt, R.C. and Nelson, R.J. (2009). Shades of gray: the world of quantitative disease resistance. Trends Plant Sci. 14: 21-29.

Quenouille, J., Montarry, J., Palloix, A. and Moury, B. (2013). Farther, slower, stronger: how the plant genetic background protects a major resistance gene from breakdown. Mol. Plant Pathol 14: 109-118.

Rantalainen, K.I., Eskelin, K., Tompa, P. and Mäkinen, K. (2011). Structural flexibility allows the functional diversity of potyvirus genome-linked protein VPg. J. Virol. 85: 2449-2457.

Richael, C. and Gilchrist, D. (1999). The hypersensitive response: 
A case of hold or fold? Physiol. Mol. Plant Pathol. 55: 5-12.

Robaglia, C. and Caranta, C. (2006). Translation initiation factors: a weak link in plant RNA virus infection. Trends Plant Sci. 11: 40-46.

Roudet-Tavert, G., Michon, T., Walter, J., Delaunay, T., Redondo, E. and Le Gall, O. (2007). Central domain of a potyvirus VPg is involved in the interaction with the host translation initiation factor eIF4E and the viral protein HcPro. J. Gen. Virol. 88: 1029-1033.

Ruffel, S., Gallois, J.L., Lesage, M.L. and Caranta, C. (2005). The recessive potyvirus resistance gene pot- 1 is the tomato orthologue of the pepper pvr2-eIF4E gene. Mol. Genet Genomics 274: 346-353.

Sacco, M.A., Mansoor, S. and Moffett, P. (2007). A RanGAP protein physically interacts with the NB-LRR protein $\mathrm{Rx}$, and is required for Rx-mediated viral resistance. Plant J. 52: 82-93.

Sakamoto, M., Tomita, R., Hamada, H., Iwadate, Y., Munemura, I. and Kobayashi, K. (2008). A primer-introduced restriction analysis-PCR-based method to analyse Pepper mild mottle virus populations in plants and field soil with respect to virus mutations that break $L^{3}$ gene-mediated resistance of Capsicum plants. Plant Pathol. 57: 825-833.

Sawada, H., Takeuchi, S., Hamada, H., Kiba, A., Matsumoto, M. and Hikichi, Y. (2004). A New tobamovirus-resistance gene, $L^{1 a}$, of sweet pepper (Capsicum annum L.). J. Jpn. Soc. Hortic. Sci. 73: 552-557.

Sekine, K.T., Ishihara, T., Hase, S., Kusano, T., Shah, J. and Takahashi, H. (2006). Single amino acid alterations in Arabidopsis thaliana RCY1 compromise resistance to Cucumber mosaic virus, but differentially suppress hypersensitive response-like cell death. Plant Mol. Biol. 62: 669-682.

Sekine, K.T., Kawakami, S., Hase, S., Kubota, M., Ichinose, Y., Shah, J., Kang, H.G., Klessig, D.F. and Takahashi, H. (2008). High level expression of a virus resistance gene, $R C Y 1$, confers extreme resistance to Cucumber mosaic virus in Arabidopsis thaliana. Mol. Plant-Microbe Interact. 21: 1398-1407.

Sekine, K.T., Tomita, R., Takeuchi, S., Atsumi, G., Saitoh, H., Mizumoto, H., Kiba, A., Yamaoka, N., Nishiguchi, M., Hikichi, Y. and Kobayashi, K. (2012). Functional differentiation in the leucine-rich repeat domains of closely related plant virusresistance proteins that recognize common avr proteins. Mol. Plant-Microbe Interact. 25: 1219-1229.

高橋英樹（2004）分子レベルから見た植物の耐病性（島本功注 か編)。pp. 182-193，秀潤社，東京.

Tavert-Roudet, G., Abdul-Razzak, A., Doublet, B., Walter, J., Delaunay, T., German-Retana, S., Michon, T., Le Gall, O. and Candresse,
T. (2012). The $\mathrm{C}$ terminus of lettuce mosaic potyvirus cylindrical inclusion helicase interacts with the viral VPg and with lettuce translation eukaryotic initiation factor 4E. J. Gen. Virol. 93: 184-193.

Tomita, R., Sekine, K.T., Mizumoto, H., Sakamoto, M., Murai, J., Kiba, A., Hikichi, Y., Suzuki, K. and Kobayashi, K. (2011). Genetic basis for the hierarchical interaction between Tobamovirus spp. and $L$ resistance gene alleles from different pepper species. Mol. Plant-Microbe Interact. 24: 108-117.

Truniger, V., Nieto, C., González-Ibeas, D. and Aranda, M. (2008). Mechanism of plant eIF4E-mediated resistance against a Carmovirus (Tombusviridae): cap-independent translation of a viral RNA controlled in cis by an (a)virulence determinant. Plant J. 56: 716-727.

Ueda, H., Yamaguchi, Y. and Sano, H. (2006). Direct interaction between the tobacco mosaic virus helicase domain and the ATP-bound resistance protein, $\mathrm{N}$ factor during the hypersensitive response in tobacco plants. Plant Mol. Biol. 61: 31-45.

Wang, M.B., Masuta, C., Smith, N.A. and Shimura, H. (2012). RNA silencing and plant viral diseases. Mol. Plant-Microbe Interact. 25: $1275-1285$.

Wang, X., Goregaoker, S.P. and Culver, J.N. (2009). Interaction of the Tobacco mosaic virus replicase protein with a NAC domain transcription factor is associated with the suppression of systemic host defenses. J. Virol. 83: 9720-9730.

Whitham, S., McCormick, S. and Baker, B. (1996). The $N$ gene of tobacco confers resistance to tobacco mosaic virus in transgenic tomato. Proc. Natl. Acad. Sci. U S A 93: 8776-8781.

Yamaji, Y., Maejima, K., Komatsu, K., Shiraishi, T., Okano, Y., Himeno, M., Sugawara, K., Neriya, Y., Minato, N., Miura, C., Hashimoto, M. and Namba, S. (2012). Lectin-mediated resistance impairs plant virus infection at the cellular level. Plant Cell 24: 778-793.

Yamanaka, T., Imai, T., Satoh, R., Kawashima, A., Takahashi, M., Tomita, K., Kubota, K., Meshi, T., Naito, S. and Ishikawa, M. (2002). Complete inhibition of tobamovirus multiplication by simultaneous mutations in two homologous host genes. J. Virol. 76: 2491-2497.

Yeam, I., Cavatorta, J.R., Ripoll, D.R., Kang, B.C. and Jahn, M.M. (2007). Functional dissection of naturally occurring amino acid substitutions in eIF4E that confers recessive potyvirus resistance in plants. Plant Cell 19: 2913-2928.

Yoshii, M., Nishikiori, M., Tomita, K., Yoshioka, N., Kozuka, R., Naito, S. and Ishikawa, M. (2004). The Arabidopsis cucumovirus multiplication 1 and 2 loci encode translation initiation factors $4 \mathrm{E}$ and 4G. J. Virol. 78: 6102-6111. 